\title{
Tingkat Pengetahuan Ibu Hamil tentang ANC Berhubungan dengan Kunjungan ANC di Puskesmas Wongsorejo
}

\author{
Rahmawati Raharjo
}

Universitas Bakti Indonesia Banyuwangi

email : raharjorahmawati@yahoo.co.id

\begin{abstract}
Abstrak
Angka kematian ibu (AKI) yang tinggi menjadi bukti kualitas pelayanan kesehatan yang masih rendah. Hal ini yang menjadikan program ANC menjadi tolak ukur keberhasian tenaga kesehatan dalam menjaga ibu hamil dengan tujuan deteksi dini resiko kehamilan. Namun, meskipun tujuan dari program antenatal care mempunyai kegunaan dan manfaat yang sangat penting bagi ibu hamil, tidak sedikit dari mereka yang kurang sadar bahkan tidak mengindahkan anjuran pelayanan kesehatan untuk melakukan kunjungan teratur. Pengetahuan ibu hamil menjadi faktor keteraturan kunjungan ANC. Jenis rancang bangun penelitian menggunakan survei analitik dengan pendekatan cross sectional adapun populasi dalam penelitian ini adalah semua ibu hamil di Puskesmas Wongsorejo pada triwulan ketiga di tahun 2017 sebanyak 150 orang, dengan menggunakan random sampling dan ditemukan 60 sampel untuk diteliti, adapun uji statistik menggunakan uji chi square (SPSS versi 20). Hasil penelitian menyatakan sebagian besar responden sebanyak 37 responden $(61,7 \%)$ mempunyai tingkat pengetahuan baik dan hampir seluruh responden sebanyak 48 responden (80\%) melakukan kunjungan ANC dengan teratur. Hasil uji statistik penelitian dapat nilai adalah 0,05 dengan $\mathrm{df}=4$, maka bisa diketahui bahwa chi square table sebesar 9,488 dengan nilai tersebut diatas maka dapat ditarik kesimpulan bahwa Chi Square hitung $>$ Chi Square table dan dinyatakan ada hubungan tingkat pengetahuan tentang ANC dengan kunjungan ANC di puskesmas Wongsorejo. Berdasarkan temuan tersebut dapat disimpulkan semakin tinggi tingkat pengetahuan ibu hamil maka semakin teratur melakukan kunjungan ANC, maka untuk meningkatkan pengetahuan ibu hamil tentang ANC disarankan untuk memperbanyak mencari informasi kesehatan melalui media cetak, internet maupun konsultasi langsung kepada tenaga kesehatan.
\end{abstract}

Kata Kunci : Tingkat pengetahuan, Kunjungan ANC

\begin{abstract}
The maternal mortality rate (MMR) still high as a fact the low quality of health services. This makes the ANC program a benchmark for the success of health workers in looking after pregnant women with the aim of early detection of pregnancy risk. However, although the purpose of the antenatal care program has very important functions and benefits for pregnant women, not a few of those who are less aware even do not heed the advice of health services to make regular visits. Knowledge of pregnant women is a regular factor in ANC visits. The research design used analytic survey with cross sectional approach. The population in this study were all pregnant women in the Wongsorejo Public Health Center in the third quarter of 2017, as many as 150 people, using random sampling and found 60 samples to be studied, the chi square test used (SPSS version 20). The results of the study stated that the majority of respondents as many as 37 respondents (61.7\%) had a good level of knowledge and almost all respondents as many as 48 respondents (80\%) made regular ANC visits. The statistical test results of the study can be a value of 0.05 with $d f=4$, it can be seen that the chi square table is 9,488. with the above values, it can be concluded that the Chi Square count> Chi Square table and stated there is a relationship between the level of knowledge of pregnant women about ANC with ANC visits to pregnant women in the Wongsorejo health center. It can be concluded that the higher the level of knowledge of pregnant women, the more regular ANC visits are carried out, so to increase the knowledge of pregnant women about ANC it is recommended to increase the search for health information through print media, the internet or direct consultation to health workers.
\end{abstract}

Key Words: Knowledge level, ANC visit

\section{Pendahuluan}

Pelayanan antenatal care (ANC) adalah pelayanan kesehatan oleh tenaga kesehatan yang diberikan kepada ibu hamil sesuai standar pelayanan (Manuaba, 2001 dalam Febyanti dkk, 2012). Menurut world health organitation (WHO) pada tahun 2011, 536.000 perempuan meninggal pada melahirkan. Bahkan di negara-negara berkembang terdapat $99 \%$ ibu dan bayi meninggal karena persalinan dan kelahiran. Laporan Survei Demografi dan Kesehatan Indonesia (SDKI) tahun 2012 mencatat AKI 359 per 100 ribu kelahiran hidup dengan penyebabnya adalah perdarahan $28 \%$, keracunan kehamilan (24\%), kejadian infeksi $(11 \%)$, persalinan lama (5\%), dan keguguran(5\%). (Komariyah, 2014).

Penyebab lain dari tingginya AKI yaitu (1) rendahnya pengetahuan dan penanggulangan komplikasi, (2) rendahnya pemerataan pelayanan kebidanan bagi ibu hamil (Wiknjosastro, 2005 dalam Puspitaningrum, 2015)

Pelaksanan antenatal dikatakan baik atau tidak disesuaikan dengan standar kunjungan minimal ANC yaitu 1 kali kunjungan di trimester I, 1 kali kunjungan di trimester II, 2 kali kunjungan di trimester III (Siringo-ringo, 
2012). Kegiatan yang dilakukan pada kunjungan ANC adalah anamnesa, pemeriksaan umum dan khusus, pemeriksaan laboratorium, pemeriksaan obstetric, pemberian imunisasi TT, permerian obat dan vitamin, perawatan payudara dan penyuluhan tentang kehamilan. Sehingga segala bentuk ketidaknormalan dari kehamilan serta resiko komplikasi pada ibu hamil dapat dicegah secara dini (Puspitaningrum, 2015). Namun, meskipun tujuan dari program antenatal care mempunyai kegunaan dan manfaat yang penting bagi ibu hamil, tidak sedikit dari mereka yang kurang sadar bahkan tidak mengindahkan anjuran pelayanan kesehatan untuk melakukan kunjungan secara teratur.

Faktor penyebabnya ibu hamil enggan melakukan kunjungan ANC yaitu jarak tempat tinggal yang jauh dari puskesmas, dukungan dari keluarga khususnya suami, tingkat pengetahuan ibu hamil serta faktor sosial ekonomi (Tamaka dkk, 2013). Penelitian Tamaka dkk (2013), pengetahuan tentang ANC berhubungan dengan kunjungan ANC. Pengetahuan ibu yang tinggi akan dapat mengetahui manfaat serta tujuan dari ANC seperti penanggulangan komplikasi kehamilan, posisi janin serta kesehatan ibu hamil sendiri sehingga dapat mencegah resiko kehamilan sedini mungkin. Upaya untuk mengatasi masalah tersebut adalah meningkatkan tingkat pengetahuan ibu hamil tentang ANC dengan memperbanyak mencari informasi baik lewat media sosial, majalah, koran maupun konsultasi Kesehatan kepada tenaga kesehatan yang lebih mengerti akan kesehatan ibu hamil. selain itu, hendaknya ibu hamil selalu melakukan kunjungan ANC untuk mengikuti program posyandu seperti senam hamil, kelas ibu hamil, penyuluhan KIA serta menjaga pola makan yang sehat sesuai yang dianjurkan kader dan tenaga kesehatan posyandu.

\section{Metode Penelitian}

Desain penelitian yang digunakan adalah survey analitik dan menggunakan pendekatan cross sectional. Populasi penelitian ini adalah ibu hamil di Puskesmas Wongsorejo pada triwulan ketiga di tahun 2017 sebanyak 150 orang. Sedangkan sampelnya adalah ibu hamil di Puskesmas Wongsorejo pada triwulan ketiga di tahun 2017 sebanyak 60 orang. Pada penelitian ini menggunakan "Random Sampling"

Instrumen yang digunakan berupa kuesioner tentang tingkat pengetahuan tentang ANC dengan format pilihan ganda. Observasi dilakukan untuk mengobservasi keteraturan kunjungan ANC pada ibu hamil melalui buku KMS. Uji Chi-Square. dipakai untuk menghitung. Data yang terkumpul akan diolah untuk mengetahui hubungan antara variabel bebas dan variabel terikat.

\section{Hasil Dan Pembahasan}

Hasil

Tingkat pengetahuan

$$
\text { Data frekuensi responden }
$$

berdasarkan tingkat pengetahuan yaitu sebagian besar responden sebanyak 37 responden $(61,7 \%)$ mempunyai tingkat pengetahuan baik, dan sebagian kecil lainnya sebanyak 6 responden (10\%) mempunyai tingkat pengetahuan kurang baik.

Tabel 1 : Distribusi frekuensi responden berdasarkan tingkat pengetahuan responden di puskesmas Wongsorejo kab. Banyuwangi tahun 2017

\begin{tabular}{l|l|l|l}
\hline \multirow{4}{*}{ Kategoin } & Pengetahuan & Frequency & Percent \\
\cline { 2 - 4 } & Baik & 37 & 61.7 \\
\cline { 2 - 4 } & Cukup & 17 & 28.3 \\
\cline { 2 - 4 } & Kurang & 6 & 10.0 \\
\cline { 2 - 4 } & Total & 60 & 100.0 \\
\hline
\end{tabular}

Pengetahuan merupakan suatu hasil mengindraan seseorang terhadap suatu objek yang dilihat, baik berupa hal positif maupun negatif yang mempengaruhi seseorang dalam berprilaku dan bersikap. Semakin banyak pengetahuan seseorang tentang suatu objek, maka semakin paham dan mengerti tata cara mengamplikasikan pengetahuan itu. Dalam arti lain, semakin tinggi pengetahuan seseorang maka semakin baikpula tingkah laku seseorang (Bambang, 2008). Faktor penunjang dari tingkat pengetahuan adalah pendidikan yang diberikan seseorang terhadap perkembangan orang lain dengan tujuannya adalah mengarahkan pada cita-cita, mengisi kehidupan dengan selamat dan bahagia.

$$
\text { Pendidikan dilakukan untuk }
$$

menyampaikan informasi tentang hal yang dapat menunjang kesehatan sehingga kualitas hidup seseorang dapat meningkat (Dewi, 2011). Hal tersebut diatas sesuai dengan hasil penelitian tentang data umum responden pada poin pendidikan yang didapatkan hasil tingkat pengetahuan responden masuk dalam kategori baik, disebabkan tingkat pendidikan responden yang bisa dikatakan berpendidikan seperti SMP sebanyak 26 responden, SMA sebanyak 24 responden dan akademik sebanyak 3 responden. Jadi responden dalam penelitian ini mayoritas berpendidikan sehingga tingkat pengetahuan responden dikatakan baik. Selain itu untuk menunjang pengetahuan ibu hamil terhadap kesehatan kehamilannya maka hendaknya responden selalu aktif dalam mengikuti program pelayanan kesehatan seperti ANC, kelas ibu hamil serta konsultasi dengan tenaga kesehatan. 
Kunjungan ANC

Berdasarkan hasil penelitian diperoleh data frekuensi responden berdasarkan kunjungan ANC yaitu hampir selurus responden sebanyak 48 responden $(80 \%)$ melakukan kunjungan ANC dengan teratur, dan sebagian kecil lainnya sebanyak 12 responden (20\%) melakukan kunjungan ANC dengan tidak teratur.

Tabel 2: Distribusi frekuensi responden berdasarkan kunjungan ANC responden di puskesmas Wongsorejo Kab. Banyuwangi tahun 2017.

\begin{tabular}{l|l|l|l}
\hline \multirow{4}{*}{ Kategon } & KunjunganANC & Frequency & Percent \\
\cline { 2 - 4 } & Teratur & 48 & 80.0 \\
\cline { 2 - 4 } & tidak teratur & 12 & 20.0 \\
\cline { 2 - 4 } & TOTAL & 60 & 100.0 \\
\hline \multirow{2}{|c|}{ care bertujuan } & $\begin{array}{r}\text { untuk } \\
\text { selama }\end{array}$ \\
Antenatal \\
mempromosikan
\end{tabular}

kehamilan., screening, identifikasi ibu hamil dengan resiko tinggi dan melakukan rujukan diperlukan, memantau kesehatan ibu dengan upaya deteksi dan mengatasi masalah yang terjadi (Padila, 2014). Faktor yang mempengaruhi kunjungan ANC salah satunya adalah umur. Tingkat kematangan dan kekuatan seseorang dipengaruhi oleh umur.

Umur ibu hamil yang matang akan mempengaruhi kematangan dalam berpikir, sehingga ibu hamil akan termotivasi untuk melakukan pemeriksaan kehamilan (Padila, 2014). Hal tersebut dapat dipadukan dengan hasil data umum responden dalam penelitian ini yang menyatakan data umur responden yaitu hampir setengah dari responden berusia $31-40$ tahun sebanyak 23 responden $(38,3 \%)$ yang artinya usia responden yang merupakan ibu hamil merupakan usia dewasa sampai dengan dewasa atas yang membuat responden telah memasuki usia yang matang dan dapat berfikir hal-hal positif dan lebih mengutamakan kesehatan daripada keperluan atau kesenangan lainnya. Dari hasil penelitian dan teori yang ada maka responden dalam kategori teratur dalam berkunjung ke ANC, hal tersebut sesuai dengan teori yang menyatakan bahwa keteratruran kunjungan ANC banyak faktor yang berhubungan salah satunya tingkat pengetahuan dan usia ibu hamil, hal ini dijawab dalam penelitian ini yang menyatakan mayoritas ibu hamil berusia dewasa sampai dewasa menengah, yang menurut teori usia tersebut merupakan usia yang dapat memotivasi diri untuk melakukan ANC dengan teratur. Hal ini dapat dijadikan suatu gambaran pada ibu hamil dalam meningkatkan frekuensi kunjungan ANC, mengingat dampak, fungsi dan manfaat dari ANC sangatlah besar bagi kesehatan ibu dan calon bayi yang dikandungnya. Selain itu untuk menjaga kesehatan ibu dan janin maka hendaknya ibu selalu melakukan pola hidup sehat mengatur pola makan serta melakukan senam hamil, sehingga ibu dapat mencegah kelainan dan gangguan selama hamil.

Hubungan tingkat pengetahuan dengan kunjungan ANC

Berdasarkan hasil penelitian diperoleh data tingkat pengetahuan dengan kunjungan ANC adalah sebagai berikut responden dengan tingkat pengetahuan baik dan melakukan kunjungan ANC dengan teratur sebanyak 36 responden, kemudian responden yang tingkat pengetahuannya kurang baik dan tidak teratur dalam kunjungan ANC sebanyak 6 responden.

Tabel 3: Tabulasi silang tingkat pengetahuan dengan kunjungan anc di puskesmas wongsorejo kab. Banyuwangi tahun 2017

\begin{tabular}{l|l|l|l|l}
\hline \multirow{2}{*}{ No } & \multirow{2}{*}{ TingkatPengetahuan } & \multicolumn{2}{|l|}{ Kunjungsn ANC } & \multirow{2}{*}{ Teratur } \\
\cline { 3 - 4 } & & $\begin{array}{l}\text { Tidak } \\
\text { Teratur }\end{array}$ & \multirow{2}{*}{ Total } \\
\cline { 3 - 4 } & & $\mathrm{N}$ & $\mathrm{N}$ & \\
\hline 1 & Baik & 36 & 1 & 37 \\
\hline 2 & Cukup & 2 & 15 & 17 \\
\hline 3 & Kurang & 0 & 6 & 0 \\
\hline \multicolumn{2}{l|}{ Jumlah } & 38 & 12 & 60 \\
\hline
\end{tabular}

Seseorang yang patuh berarti orang tersebut menyadari manfaat dari melakukan sesuatu. Seseorang menyadari manfaat melakukan sesuatu ketika sebelumnya mempunyai pengetahuan yang baik tentang sesuatu tersebut.. Pengetahuan merupakan salah satu faktor penunjang dari perilaku. Perilaku berdasar atas pengetahuan akan bertahan lebih lama. Sangat penting memberikan pendidikan kesehatan kepada ibu hamil supaya ibu hamil dapat menyadari pentingnya ANC dan berupaya meningkatkan pengetahuannya (Niken, 2012).

Hasil uji statistik penelitian dapat disimpulkan dengan diketahuinya rumus uji Chi Square dari hasil uji SPSS versi 17 didapatkan nilai adalah 0,05 dengan $\mathrm{df}=4$, maka bisa diketahui bahwa chi square table sebesar 9,488. dengan nilai tersebut diatas maka dapat ditarik kesimpulan bahwa Chi Square hitung > Chi Square table dan dinyatakan ada hubungan antara variabel tingkat pengetahuan dengan variabel kunjungan ANC di puskesmas Wongsorejo.

Tabel 4. Uji Statistik Chisquare

\begin{tabular}{l|l|l|l}
\hline Variabel & $\begin{array}{l}\text { Pearson } \\
\text { Chi- } \\
\text { Square }\end{array}$ & Df & $\begin{array}{l}\text { Asymp. Sig. } \\
\text { (2-sided) }\end{array}$ \\
\hline $\begin{array}{l}\text { Tingkat } \\
\text { pengetahua } \\
\text { n- } \\
\text { kunjungan }\end{array}$ & 68,460 & 4 & 0,000 \\
\hline
\end{tabular}




\begin{tabular}{l|l|l|l}
\hline Variabel & $\begin{array}{l}\text { Pearson } \\
\text { Chi- } \\
\text { Square }\end{array}$ & Df & $\begin{array}{l}\text { Asymp. Sig. } \\
\text { (2-sided) }\end{array}$ \\
\hline ANC & & & \multicolumn{3}{|c}{ silang dan hasil uji }
\end{tabular}

statistik dan penelitian terdahulu serta ditunjang oleh teori yang ada, maka penelitian ini dapat dikatakan ada hubungan antara tingkat pengetahuan dengan keteraturan kunjungan ANC, hal tersebut diatas menyatakan bahwa adanya dampak dari suatu pengetahuan terhadap minat ibu untuk melakukan ANC yang artinya semakin tinggi pengetahuan seorang ibu hamil, maka akan berbanding lurus dengan kunjungan ANC. Maka dari itu hendaknya responden melakukan kunjungan ANC untuk melakukan pemeriksaan, deteksi dini dan konsultasi kesehatan dengan tenaga kesehatan untuk menambah pengetahuan ibu hamil tentang kesehatan ibu dan anak, sehingga ibu dengan teratur mengikuti ANC yang mempunyai manfaat untuk menjaga kesehatan ibu hamil dan calon bayi yang dikandungnya.

\section{Pembahasan}

Faktor- faktor yang Mempengaruhi Pemberian ASI Eksklusif berdasarkan pengetahuan

Tabel 1 diatas menunjukkan bahwa sebagian besar (50,0\%) memiliki pengetahuan cukup tentang ASI eksklusif. Pengetahuan (knowledge) adalah hasil dari tahu dan ini terjadi setelah orang melakukan pengindraan, rasa dan raba. Sebagian besar pengetahuan manusia diperoleh dari mata dan telinga. Pengetahuan atau kognitif merupakan dominan yang sangat penting dalam membentuk tindakan seseorang (Notoatmodjo, 2010).

Hasil penelitian ini sejalan dengan penelitian Arum Apriliyana (2011) tentang "Faktor-faktor Yang Mempengaruhi Kegagalan Pemberian ASI Eksklusif Pada lbu Menyusui di Desa Adipala Kabupaten Cilacap Tahun 2011", didapatkan hasil sebagian besar ibu mempunyai pengetahuan cukup tentang ASI.

Pengetahuan merupakan hasil stimulasi informasi yang diperhatikan dan diingat. Informasi tersebut bisa berasal dari pendidikan formal mapun non formal, percakapan, membaca, mendengar radio, menonton televisi, dan pengalaman hidup. Dari penelitian telah terbukti bahwa perilaku seseorang yang didasari oleh pengetahuan akan lebih langgeng dari pada perilaku yang tidak didasari oleh pengetahuan (Notoadmojo, 2010).

Faktor- faktor yang Mempengaruhi
Pemberian ASI Eksklusif berdasarkan umur Tabel 2 diatas menunjukkan bahwa sebagian besar $(62,5 \%)$ berasal dari kelompok umur 20 35 tahun. . Menurut Notoatmodjo tahun 2010, semakin cukup umur seseorang maka tingkat kematangan dan kekuatan seseorang akan lebih matang dalam berfikir dan bekerja. Dari segi kepercayaan masyarakat, seseorang yang lebih dewasa akan lebih dipercayai daripada orang yang belum cukup tinggi kedewasaannya. Hal ini sebagai akibat dari pengalaman dan kematangan jiwanya, makin tua seseorang maka semakin kondusif dalam menggunakan koping terhadap masalah yang dihadapi (Azwar, 2009).

Faktor- faktor yang Mempengaruhi Pemberian ASI Eksklusif berdasarkan pendidikan

Tabel 3 menunjukkan bahwa sebagian besar $(52,5 \%)$ dengan pendidikan menengah. Pendidikan orang tua merupakan salah satu faktor dalam tumbuh kembang anak, karena tingkat pendidikan ibu yang rendah mengakibatkan kurangnya pengetahuan ibu dalam pemberian ASI eksklusif (Kasmayanti, 2010). Pendidikan akan membuat seseorang terdorong untuk ingin tahu, untuk mencari pengalaman. Pengetahuan yang dimiliki akan membentuk suatu keyakinan untuk melakukan perilaku tertentu dalam pendidikan pemberian ASI eksklusif (Haryono,2014)

Faktor- faktor yang Mempengaruhi Pemberian ASI Eksklusif berdasarkan pekerjaan

Pada tabel 4 diatas didapat bahwa sebagian besar $(70,0 \%)$ responden bekerja. Responden yang memiliki perkerjaan formal lebih cenderung tidak menyusui secara eksklusif. Menurut Roesli (2013), bekerja bukan alasan untuk menghentikan pemberian ASI secara eksklusif selama 6 bulan. Dengan pengetahuan yang benar tentang menyusui, adanya perlengkapan memerah ASI dan dukungan lingkungan kerja, seorang ibu yang bekerja dapat tetap memberikan ASI secara eksklusif.

Faktor- faktor yang Mempengaruhi Pemberian ASI Eksklusif berdasarkan paritas Pada tabel 5 didapat informasi bahwa sebagian besar $(85,0 \%)$ berasal dari paritas multipara. Paritas adalah jumlah anak yang pernah dilahirkan baik hidup maupun mati. Pravelansi menyusui eksklusif meningkat dengan bertambahnya jumlah anak, dimana anak ketiga atau lebih akan banyak disusui secara eksklusif dibandingkan anak kedua atau pertama, sehingga paritas mempengaruhi pemberian ASI eksklusif (Suparmanto dan Rahayu, 2011).

Faktor- faktor yang Mempengaruhi 
Pemberian ASI Eksklusif berdasarkan dukungan suami

Pada tabel 6 didapat informasi bahwa sebagian besar (82,5\%) mendapatkan dukungan dari suami dalam pemberian ASI eksklusif. Hasil penelitian ini sejalan dengan penelitian oleh Isroni Astuti (2013) tentang Determinan Pemberian ASI Ekslusif pada Ibu menyusui menunjukkan terdapat hubungan yang signifikan antara dukungan suami dalam pemberian ASI Eksklusif.

\section{Kesimpulan Dan Saran}

a. Frekuensi responden berdasarkan tingkat pengetahuan yaitu sebagian besar responden sebanyak 37 responden $(61,7 \%)$ mempunyai tingkat pengetahuan baik. Hal tersebut disebabkan oleh tingkat pendidikan responden yang mayoritas SMA bahkan ada yang lulusan akademik sehingga tingkat pengetahuan mereka tinggi tentang saseuatu termasuk kesehatan.

b. Frekuensi responden berdasarkan kunjungan ANC yaitu hampir selurus responden sebanyak 48 responden $(80 \%)$ melakukan kunjungan ANC dengan teratur. Hal ini disebabkan oleh paritas responden yang dinyatakan merupakan kandungan pertama dan kedua sehingga rasa kewaspadaan dan kekhawatiran sangat tinggi dan membuat responden melakukan kunjungan ANC dengan teratur.

c. c. Hasil uji statistik penelitian dapat disimpulkan dengan diketahuinya rumus uji Chi Square dari hasil uji SPSS versi 17 didapatkan nilai adalah 0,05 dengan $\mathrm{df}=4$, maka bisa diketahui bahwa chi square table sebesar 9,488. dengan nilai tersebut diatas maka dapat ditarik kesimpulan bahwa Chi Square hitung > Chi Square table dan dinyatakan tingkat pengetahuan ibu hamil tentang ANC berhubungan dengan kunjungan ANC pada ibu hamil di puskesmas Wongsorejo.

\section{Daftar Pustaka}

Bambang, (2008). Buku Ajar Keperawatan Maternitas. Edisi 4. Jakarta : EGC.

Dewi \& Wawan, (2010). Dasar Keperawatan Maternitas. Edisi 6. Jakarta: EGC.

Farrah dkk, (2016). Asuhan Kebidanan dengan Fisiologi Trimester III. 2009. http://www.scribd.com/doc/243136 17/Asuhan-Kebidanan-dengan-
FISIOLOGI-TRIMESTER-III

Febyanti dkk, (2012). Hubungan Pengetahuan, Sikap Ibu Hamil Terhadap Kunjungan Pelayanan Antenatal di Kecamatan Kalimanah Kabupaten Purbalingga. Jurnal Media Litbang Kesehatan, Volume XI nomor 1.

Hidayat, (2009). Metodologi Penelitian Kebidanan DII, DIV, S1 dan S2. Nuha Medika:Yogyakarta

Kemenkes RI, (2013). Pusat Data Surveilans Epidemiologi Profil Kesehatan Indonesia. Jakarta: Kementerian Kesehatan RI.

Keraf dan Mikhael (2008). Advance Learner's Dictionary of Education. New Delhi: Anmol Publications PVT. LTD. Hal 67.

Komariyah, (2014). Hubungan Pengetahuan Ibu Hamil Tentang Antenatal Care Dengan Jumlah Kunjungan Antenatal Care di Desa Laut Dendang Kecamatan Percut Sei Tuan Kabupaten Deli Serdang Medan. Skripsi Tidak Diterbitkan. Medan:

Mubarok, dkk, (2007). Buku ajar Kesehatan Reproduksi Wanita. Jakarta: Renika Cipta.

Manuaba (2013). IImu Kebidanan. Edisi III. Jakarta: Yayasan Bina Pustaka

Notoadmodjo, (2010). Pengantar IImu Statistik penelitian. Jakarta:Renika Cipta.

Notoatmodjo, (2012). Pendidikan dan Perilaku Kesehatan. Jakarta: Rineka Cipta.

Nursalam (2011). IImu Kebidanan, Penyakit Kandungan dan KB untuk Pendidikan Bidan. Jakarta : EGC.

Nursalam, (2013). Konsep dan Penerapan Metodelogi Penelitian IImu Keperawatan Edisi 2. Jakarta : Salemba Medika.

Nyna, (2015). Kematian Ibu, Petaka yang Sulit Surut. (Online) (http://www.majalahfarmacia.co.id, diakses tanggal 8 Juni 2017)

Padila, (2014). Sinopsis Obstetri: Obstetri Fisiologi, Obstetri Patologis. Jakarta : EGC

Prawiroharjo, (2012). Asuhan Kebidanan Kehamilan. In Media. Jakarta

Puspitaningrum, (2015). Hubungan Tingkat Pendidikan Dengan Tingkat Pengetahuan Tentang Antenatal Care Dalam Kalangan Usia Subur di Puskesmas Padang Bulan. Ejurnal FK USU, Volume 1 no1

Riduan (2010). Metode Penelitian Keperawatan dan Teknik Penulisan Ilmiyah. Jakarta : Salemba Medika.

Riyanto, (2010). Pengantar IImu Statistik penelitian. Jakarta: Rineka Cipta.

Saifuddin, (2012). IImu Kebidanan, Penyakit Kandungan dan Keluarga Berencana Untuk Pendidikan Bidan. Jakarta: EGC

Setiadi, (2009). Kapita Selekta 
Penatalaksanaan Rutin Obstetrik Ginekologi dan KB. Jakarta: EGC.

Siringo-ringo, (2012). Pelayanan Kesehatan Maternal dan Neonatal. Jakarta: Yayasan Bina Pustaka

Sugiyono, (2011). Metode Penelitian Keperawatan dan Teknik Penulisan Ilmiyah. Jakarta : Salemba Medika

Sugiyono, (2007). Metode Penelitian Keperawatan dan Teknik Analisa Data. Jakarta : Salemba Medika.

Sullivan et al , (2009). Nursing Research The Application of Qualitatif Approach. Second edition. United Kingdom: Nelson Thomas Ltd.

Tamaka dkk, (2013). Panduan pemeriksaan antenatal. Jakarta: EGC

Wibowo, (2007). Buku Acuan Nasional Pelayanan Kesehatan Maternal dan Neonatal. Jakarta: Yayasan Bina Pustaka

Wiknjosastro, (2009). Pendidikan dan Perilaku Kesehatan. Jakarta: Rineka Cipta. 